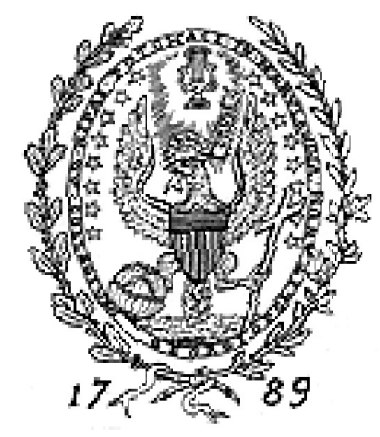

Bioethics Research Library

The Joseph and Rose Kennedy Institute of Ethics

Box 571212, Georgetown University

Washington, DC 20057-1212

202-687-3885; fax: 202-687-8089

bioethics@georgetown.edu

http://bioethics.georgetown.edu

\title{
Animals in Research and Education: Ethical Issues
}

\author{
Laura Jane Bishop \\ Anita Lonnes Nolen \\ Revised March, 2001
}

Scientific enquiry is inexorably tied to animal experimentation in the popular imagination and human history. Many, if not most, of the spectacular innovations in the medical understanding and treatment of today's human maladies have been based on research using animals. However, the use of animals in research and experimentation has been debated, defended, and protested by both individuals and organizations at various levels. Responses range from personal lifestyle decisions and fervent philosophical treatises to strident arguments, violent demonstrations, and direct action. The continuum of attitudes about animals and the human relationship with animals spans the range between those who support no regulation of the human use of animals and those who advocate absolute animal liberation from all human use (see II, Orlans 1993, p. 22).

\section{History}

The first recorded experimentation on animals occurred in ancient Rome, but not until the Renaissance did scholars begin serious study of how the body works. Leonardo da Vinci (1452-1519) and other artists and anatomists pursued anatomical investigations of muscle and bone structure. William Harvey (1578-1657) discovered the circulation of the blood via his experiments on live deer. During this period, much live animal experimentation both in England and France was based on the view of French philosopher René Descartes (1596-1650) that animals are incapable of feeling pain. Jeremy Bentham (1748-1832), the English utilitarian philosopher, thought otherwise. In his "Introduction to the Principles of Morals and Legislation" in 1789, Bentham declared, "The question is not 
can they reason? Nor, can they talk, but can they suffer." Despite Bentham and others, the belief that animals could not perceive pain persisted in many quarters into the twentieth century. Nineteenth century French physiologist Claude Bernard (1813-1878)-and his teacher, François Magendie (1783-1855)-conducted wide-ranging animal experiments including surgery, use of drugs, and removal of body parts from many species. Bernard argued that while no amount of benefit could justify any harm to human research subjects, even extreme harm and pain for animal research subjects could be justified by the potential benefit to human beings. Although he did use anesthetics in his work after their discovery in 1847, even Bernard's later work was controversial because of the numbers of animals used and the repetitive nature of his research. The experiments of Magendie and Bernard both laid the foundations for animal experimentation as a practice for scientific advance and contributed in large measure to the emergence of the antivivisection movement. Public protests over animal experiments conducted in France and the fear that these might come to England led to the passage of the first law controlling animal experimentation, the "1876 Cruelty to Animals Act" in England. This history and the dynamic tension between scientific inquiry and public concern set the stage for the activism and scholarship of the twentieth century.

Since the 1960s, the amount of attention, activism, and scholarship related to animal use has increased at a rapid pace. The modern animal protection movement, led by the Australian philosopher Peter Singer in his book, Animal Liberation (II, 1975), based its advocacy on animals' ability to experience pain and suffering (Bentham's argument). Singer's book and other investigations into animal research, such as LIFE magazine's photojournalism piece on pet theft, animal cruelty, and animal experimentation (Concentration Camps for Dogs. LIFE (4 February 1966), pp. 22-29), brought the use of animals in research, testing, and education to the attention of the general public. Activists, advocates, laypersons, scientists, lawmakers, and animals themselves, have created

\section{TABLE OF CONTENTS}

Introduction. . . . . . . . . . . . . . . . . 1

I. General Resources

A. Databases...... . . . . . . . . . . . . 5

B. Websites, Journals, Books. . . . . . . . 6

II. Philosophical and Religious

Perspectives. . . . . . . . . . . 8

III. Regulating Animal Experimentation. . . . 12

IV. Special Topics
A. Genetic Manipulation of Animals... . 12
B. Great Apes. . . . . . . . . . . . . . . 14
C. Rats, Mice, and Birds. . . . . . . . . 16
D. Science Education and the Use of Animals................... 16
E. Xenotransplantation............ . 17

the interesting, complicated, and complex history of animal rights and animal welfare over the last several decades.

\section{Current Statistics}

Worldwide, approximately 35 million animals are used in research each year; the United States alone uses 12 million animals annually--more than any other country. In 1998, the official number of research animals recorded in the United States was $1,213,814$. However, this number must be increased tenfold to account for laboratory rats, mice, and birds, which comprise about 90 percent of all animals used in research, but are not covered by the Animal Welfare Act (AWA), and therefore, are not counted. The most frequently used species in the United States is mice, followed by rats, rabbits, guinea pigs, pigs, dogs, sheep, primates, and cats. The annual Animal Welfare report prepared by the U.S. Department of Agriculture's Animal and Plant Health Inspection Service contains annual statistics for animals used 
in U.S. research (http://www.aphis.usda.gov/ac/ publications.html). Animal research data for other countries may be found at national web sites, but reporting requirements vary around the globe and generally emanate from regulations governing the use and treatment of animals in research. Nowadays, the purpose of most experiments is to help treat human disease; a small amount of experimentation involving animal pain or death is for educational purposes. Although some countries still conduct unregulated animal research, more than 20 countries have specific legislation governing the humane use of animals in biomedical research and education. These include the U.S., Canada, all countries in the European Union, Australia and New Zealand, and Japan. Much of this legislation is more stringent than that in the U.S. Typical legislation requires adequate housing conditions, controls on animal pain, and critical prior review of experimental protocols. Some countries, such as the U.S., also include provisions for the use of animal alternatives (see the 3 R's below), and a few require some explicit ethical justification for the use of animals in harmful experiments. Several websites list international animal welfare legislation and guidelines, along with explanations ( see http://altweb.jhsph.edu/ science/regs/reg.htm).

\section{Main Features of U.S. Legislation}

In the United States, the use of animals in biomedical research is regulated by two federal laws, the Public Health Service Guide for the Care and Use of Laboratory Animals, administered by the Office for Laboratory Animal Welfare of the National Institutes of Health (NIH), and the Animal Welfare Act, administered by the Animal and Plant Health Inspection Service (APHIS) of the United States Department of Agriculture (USDA). The AWA controls research involving only the specifically named animal species, while the Public Health Service (PHS) guidelines regulate any animal research supported by federal funds-e.g., animal research in all federal agencies. The full text of these laws and other regulations is available online at: http: //www.nal.usda.gov/awic/legislat/awicregs.htm.

The PHS regulations, which are rooted in the 1963 standards for animal care and use developed by scientists gathered by the Institute of Laboratory Animals Resources of the National Research Council and in the 1971 guidelines issued by the National Institutes of Health, were first published in 1973 and revised in 1979 and 1986. Although the policies at first were voluntary and addressed only standards for animal husbandry, under the Health Research Extension Act of 1985 (Public Law 99-158), the guidelines became law and now describe requirements for experimental animal procedures conducted by all federal agencies. NIH, a branch of the PHS, has been responsible for administering federal grants for animal experiments since 1946. The PHS guidelines established the oversight system of Institutional Animal Care and Use Committees (IACUCs) to evaluate research protocols, review care programs and inspect laboratory facilities, assess and educate laboratory personnel, and investigate complaints about the misuse or mistreatment of animals.

The Animal Welfare Act, first adopted in 1966 as a result of mounting public concern about animal research, and amended in 1970, 1976, 1985, and 1990, compels registration of animal research facilities with the USDA, sets minimum standards for the general and veterinary care of animals used in research, requires inspections of laboratory facilities, and adopts the use of local IACUCs to review research protocols for compliance with regulations governing research and measures to promote animal welfare. At first, the law (Public Law 89-544) regulated the humane treatment in research of only six species: dogs, cats, hamsters, guinea pigs, rabbits, and nonhuman primates. The 1970 amendment authorized the Secretary of Agriculture to include additional warm-blooded animals within its purview, and gave the legislation its current name. As a result of this amendment, research on farm animals is governed 
by the AWA. Other amendments to the AWA required the use of pain-relieving drugs (Improved Standards for Laboratory Animals Act of 1985), adopted the IACUC oversight system, and extended coverage to include college and university student work with animals. The U.S. National Agricultural Library established the Animal Welfare Information Center in 1986 to serve as a resource and education center about animal welfare and the AWA.

One difficulty with this present situation is that animal research conducted by pharmaceutical companies or genetic engineering firms often falls outside the federal regulations. Because it neither involves named species nor is supported by federal funds, this research is not governed by the requirements of law. This fact is one of the main driving forces behind the efforts to include rats, mice, and birds under the AWA. A lawsuit filed against the USDA in 1998, ARDF v. Glickman (U.S. Secretary of Agriculture), eventually won coverage of those species when it was settled out of court in September 2000. However, although the USDA is now ready to draft regulations, the FY 2001 Congressional appropriations bill specifically states that no USDA monies can be used for this purpose, thereby effectively delaying any further action.

\section{The "3 R's"}

In recent years, the concern within the scientific community and in the general public over the use of nonhuman animal subjects in research and education has taken focus and direction from the 1959 book, The Principles of Humane Experimental Technique by W. M. S. Russell and R. L. Burch, which laid out the concept of the "Three R's" for the first time, and thereby, inspired the movement for alternatives to the use of animals in biomedical research and testing. The "Three R's" are: replacement of conscious living animals with nonsentient animals or materials, reduction of the number of animals used in an experiment or procedure, and refinement of the techniques used in order to decrease the incidence or amount of animal pain and distress. Russell and Burch believed that following the 3 R's would result in more ethical and humane treatment of animals. These concepts have been adopted by a number of scientists and many animal advocacy organizations and have been written into the laws of several countries.

\section{Animals in Education}

Another area in which animal alternatives are sought is in education. At the graduate or professional level, experimentation or surgery on live animals (vivisection) raises a host of concerns about unnecessary pain and suffering and the unethical use of animals. At some veterinary and medical schools, students have refused to do nontherapeutic surgery on healthy animals or to kill them. Several veterinary schools now teach animal surgery by using only animals that are in need of surgery. Similarly, many medical schools have eliminated their live-animal labs or have reduced the number of healthy animals they use for surgical practice. At the middle, secondary, and college levels, the major focus has been to eliminate all experiments that involve infliction of pain on live vertebrate animals and to reduce or eliminate animal dissection, which became a regular part of the American high school biology curriculum in the 1920s, and was common in U.S. colleges as early as the late 1800 s (IV. D., Balcombe 2000). Animal dissection raises many ethical and environmental concerns: the practice involves the unnecessary killing of animals; undermines conservation efforts; ignores welfare standards during animal capture, preparation, and shipping; releases formaldehyde into the environment; focuses on descriptive biology to the detriment of creative scientific thinking and research; causes some students to abandon further science education or careers; and weakens the respect for life and the humane treatment of animals. Justification for the use of dissection and vivisection in education may be lessened by Balcombe's distinction that in education, animals 
generally are used as a means to transfer existing knowledge from one person (the teacher or instructor) to another (the student), either by demonstration or by direct experience, rather than as a method to advance existing knowledge. He does acknowledge, though, that what students learn may enable them to advance human knowledge in the future. Persons who support dissection and vivisection argue that these practices provide better quality education, offer the best preparation for scientific careers, and are justified if the animals are treated humanely.

Alternatives to the use of live or dead animals, such as interactive 3-D computer models, video footage, and plastic life-size models, have been shown to be as effective as traditional methods. A number of states have humane education laws that require teaching students about the important role of animals and birds in the natural universe and teaching them that kind, just, and humane treatment and protection should apply to all animals. Some states also have dissection choice legislation, which permits students to select educational alternatives to dissection. Discussion materials, alternative resource catalogues, and guidance on creating dissection choice policies are available from organizations such as the Ethical Science and Education Coalition (ESEC). The role animals play in education now is just as likely to include a featured role in courses on animal ethics, animal welfare, and animal rights at all educational levels and fields.

\section{Genetic Manipulation of Animals}

Advances in genetics have produced cloned animals (not covered in this Scope Note) and transgenic animals, in which there has been a deliberate modification of the genome so that it contains foreign DNA. In transgenic animals, recombinant DNA technology is used to make a heritable or nonheritable modification so that the resulting animals, or their offspring, might be used to study the biology of genetic regulation and the influence of certain proteins or hormones in the body, to produce specific proteins or hormones, to test the toxicity of drugs or other interventions, and/or to improve growth and yields in agriculture. This type of genetic alteration goes beyond selective breeding for desired traits because it inserts genetic material foreign to the animal's genome. One potential use for this technology is to create animals with organs or tissue suitable for transplant to humans - xenotransplantation. Nuclear transfer or other techniques can be used to clone animals either to preserve a genetically altered animal or to create identical animal lines. Polly, a sheep created by PPL Therapeutics of Edinburgh, Scotland (who also created Dolly, the first cloned animal), was the first transgenic animal to be cloned. Born in September 1997, her genome contained a human gene that would cause her to produce alpha-1-antitrypsin, a human blood protein used to treat cystic fibrosis, in her milk. ANDi, the first genetically-altered primate was born in January 2001.

Although this Scope Note focuses on animal use in research and education, other areas also raise ethical concerns about animal rights and animal welfare. These include the use of animals as companions, in agriculture, in zoos, for entertainment or sport, and the treatment of wildlife and endangered species. This bibliography contains only a small portion of the vast amount of materials available; more can be found in the resources that have been included.

Note: Included below are databases, Websites, print and online periodicals, and general books. The format of resource information is often overlapping, so we have included all types of general information in this one list. Annotations have been omitted when information is readily available to researchers with Internet access. Finally, these URLs were last accessed in January 2001. We regret that some addresses may be changed before you use this document.

\section{General Resources}




\section{A. Databases}

Johns Hopkins Center for Alternatives to Animal Testing [CAAT] -http://caat.jhsph.edu

This site is the home of Altweb-an international online clearinghouse of alternatives resources - http://altweb.jhsph.edu.

National Reference Center for Bioethics Literature (NRCBL), Kennedy Institute of Ethics - http://bioethics.georgetown.edu.

To search the BIOETHICSLINE database of journal articles and other document types for literature on: animal care committees, animal experimentation, animal organs, animal rights, animal testing alternatives, or transgenic animals, enter the selected term from the above list in the "search query box" provided using the following format: /*animal care committees (kw). BIOETHICSLINE and the other Internet Grateful Med databases will not be available after June 2001. We encourage you to search and download the animal experimentation literature before then. After that time contact NRCBL for assistance.

To access citations to hundreds of books on: animal rights, animal experimentation, or animal production, search 22.1, 22.2, or 22.3, respectively, as SUBJECTS in the GEORGE catalog (http://library.georgetown.edu/search/).

\section{B. Websites, Journals, Books}

Animal Welfare, quarterly, Universities Federation for Animal Welfare (UFAW) at http://www.ufaw.org.uk or http://journal@ufaw. org.uk.

Animal Welfare Information Center [AWIC], National Agricultural Library, United States Department of Agriculture; http://www. nal. usda.gov/awic/; offers the quarterly $A W I C$ Bulletin online.

Animal Welfare Institute; http://www.awionline. org; offers AWI Quarterly online.

Animals' Voice Online, bimonthly, online at $\mathrm{http} / / / \mathrm{www}$.animalsvoice.com

Australian and New Zealand Council for the Care of Animals in Research and Teaching-[ANZCCART]; http://www.adelaide. edu.au/ANZCCART/; offers a quarterly newsletter online.

Bekoff, Marc, with Meaney, Carron A., eds. Encyclopedia of Animal Rights and Animal Welfare. Westport, CT: Greenwood Press, 1998. $446 \mathrm{p}$.

This collection of short essays covers many topics relating to animal welfare and the use of animals by humans, including "Laboratory Animal Use," "Antivivisectionism," "Alternatives to Animal Experiments," and "Education and the Use of Animals." An appendix lists numerous organizations as additional resources that can provide educational materials concerning animal rights and animal welfare.

Bridging the Gap: Newsletter of The Great Ape Project-International, full-text online at: http://www.greatapeproject.org/newsletters/.

Canadian Council on Animal Care. Ethics of Animal Investigation. Ottawa: The Council, 1989. [Online]. http://www.ccac.ca

Donnelly, Strachan, and Nolan, Kathleen, eds. Animals, Science and Ethics. Hastings Center Report. 20 (3, May/June), 1990. [Special Supplement]. 32 p.

This report discusses the moral status of animals; justification of animal experimentation; animal suffering; policies and practices in using animals for research and education; alternatives to animal use; and regulation and the role of animal care and use committees.

Fund for the Replacement of Animals in Medical Experiments [FRAME] (United Kingdom); 
http://www.frame-uk.demon.co.uk; publishes the journal ATLA (Alternatives to Laboratory Animals), bimonthly, partially available online.

Humane Society of the United States [HSUS]; http://www.hsus.org.

Kraus, A. Lanny, and Renquist, David, eds. Bioethics and the Use of Laboratory Animals: Ethics in Theory and Practice. Dubuque, IA: Gregory C. Beniot, 2000. 233 p.

Lab Animal: Information, Ideas, Methods \& Materials for the Animal Research Professional, 11 issues per year, Nature Publishing, partially online at http://www.labanimal.com/.

Manzo, Bettina. The Animal Rights Movement in the United States, 1975-1990: An Annotated Bibliography. Metuchen, NJ: Scarecrow Press, 1994. $296 \mathrm{p}$.

Murray, Thomas H., and Mehlman, Maxwell, J., eds. The Encyclopedia of Ethical, Legal, and Policy Issues in Biotechnology. New York: John Wiley \& Sons, 2000. 2 volumes.

See any of the many articles that address a broad array of issues arising from the intersection of biotechnology and animals, e.g., "Patents and Licensing, Ethics, Ownership of Animals and Plant Genes;" "Research on Animals, Law, Legislative and Welfare Issues in the Use of Animals for Genetic Engineering and Xenotransplantation;" and "Transgenic Animals: An Overview."

National Association for Biomedical Research; http://www.nabr.org/labanimalissues.html.

National Research Council. Institute of Laboratory Animal Resources. Committee on Pain and Distress in Laboratory Animals. Recognition and Alleviation of Pain and Distress in Laboratory Animals. Washington, DC: National Academy Press, 1992. 137 p.

Netherlands Centre Alternatives to Animal Use
[NCA]; http://prex.las.vet.uu.nl/nca/; publishes NCA Newsletter.

New Scientist, weekly, Reed Business I $\mathrm{n} \mathrm{format}$ i o $\mathrm{n}, \quad$ o n $1 \mathrm{ine}$ a $\mathrm{t}$ http://www.newscientist.com.

People for the Ethical Treatment of Animals; http://www.peta.org.

Psychologists for Ethical Treatment of Animals; http://www.psyeta.org: Journal of Applied Animal Welfare Science (JAAWS), quarterly, Lawrence Erlbaum Associates, some abstracts online; and Society \& Animals: Journal of Human-Animal Studies, three times per year, Brill, free, full-text online for volumes 1-8.

Reich, Warren T., ed. Encyclopedia of Bioethics. New York: Macmillan, 1995. 5 volumes.

See articles entitled: "Animal Research," "Animal Welfare and Rights," "Veterinary Ethics," and "Xenografts." "Ethical Directives Pertaining to the Welfare and Use of Animals" comprises Section V of the Appendix.

Rollin, Bernard E. An Introduction to Veterinary Medical Ethics: Theory and Cases. Ames, IA: Iowa State University Press, 1999. 417 p.

Russell, W. M. S., and Burch, R. L. The Principles of Humane Experimental Technique. London: Methuen \& Co., 1959. 238 p.

The authors introduced the concept of the 3 R's-Replacement, Reduction and Refinement.

Shapiro, Kenneth Joel. Animal Models of Human Psychology: Critique of Science, Ethics, and Policy. Seattle: Hogrefe \& Huber, 1998. 328 p.

Using eating disorders as a case study, Shapiro, the Executive Director of Psychologists for the Ethical Treatment of Animals, examines ethical issues in psychology's use of animals in research and provides the field's official position on animal welfare and use.

SSEA Newsletter, biannual, online, Society for the 
Study of Ethics \& Animals at http://www.phil. vt.edu/ssea.html.

University of California, Davis, Center for Animal Alternatives (UCCAA); http://www.vetmed. ucdavis.edu/Animal_Alternatives/main.htm and the Center for Animal Welfare; http:// animalwelfare.ucdavis.edu.

\section{Philosophical and Religious Perspectives}

Adams, Carol J., and Donovan, Josephine, eds. Animals \& Women: Feminist Theoretical Explorations. Durham: Duke University Press, 1995. $381 \mathrm{p}$.

This collection of essays explores the theoretical connections between feminism and animal advocacy and the historical connections between women and animals.

Cavalieri, Paola, ed. Nonhuman Personhood. Etica \& Animali 9, 1998. 127 p. [Special Issue]

Philosophical essays address the question of whether nonhuman persons exist. Topics include moral principles and speciesism, animal minds, personhood and great apes, dolphins, and elephants, and a historical overview of the concept of a "person."

Clark, Stephen R. L. Animals and Their Moral Standing. New York: Routledge, 1997. 194 p.

In this collection of essays, Christian philosopher Clarke explores a variety of topics to support his claim that "all creatures with feelings and wishes [he argues that animals fall into this group] should be thought of as ends-inthemselves, and not merely as means."

DeGrazia, David. Taking Animals Seriously: Mental Life and Moral Status. Cambridge: Cambridge University Press, 1996. 302 p.

DeGrazia provides a short philosophical history and orientation to theories of animal ethics. He uses a coherence or reflective equilibrium model of justification to argue that "many animals have moral status and that much of our current use of animals is ethically indefensible" and incoherent. Drawing on philosophical theory and empirical data, he affirms a principle of equal consideration for animals, but identifies relevant differences between individuals who bear moral status, even as he demonstrates that self-awareness, language, and other features of mental life can be found in animals.

Donovan, Josephine, and Adams, Carol J., eds. Beyond Animal Rights: A Feminist Caring Ethic for the Treatment of Animals. New York: Continuum, 1996. $216 \mathrm{p}$.

The editors argue that care theory is more appropriate for animals than rights theory. Care theory does not privilege rationality, acknowledges unequal relationships, values the emotions, and considers sympathy, empathy, and love to be moral responses.

Finsen, Lawrence, and Finsen, Susan. The Animal Rights Movement in America: From Compassion to Respect. New York: Twayne, 1994. $309 \mathrm{p}$.

Offering an account of the historical antecedents, participating organizations, political concerns and tactics, and philosophies of and opposition to animal rights, the authors also address the influence of environmentalism, ecofeminism, and animal liberation on the movement.

Frey, R. G. Interests and Rights: The Case Against Animals. Oxford: Clarendon Press, 1980. $176 \mathrm{p}$.

Frey provides an early philosophical account of why animals have no interests, and therefore lack significant moral status.

Gluck, John P.; DiPasquale, Tony; and Orlans, F. Barbara, eds. Applied Ethics in Animal Research: Philosophy, Regulation and Laboratory Applications. West Lafayette, IN: Purdue University Press, Forthcoming 2001.

Greek, C. Ray, and Greek, Jean Swingle. Sacred Cows and Golden Geese: The Human Cost of 
Experiments on Animals. New York: Continuum, 2000. $256 \mathrm{p}$.

Anesthesiologist and veterinarian respectively, the authors argue that the continued use of animals in research is unnecessary to develop new drugs, technologies, or medical techniques beneficial to human beings. Not only is animal experimentation unethical and cruel, but "extrapolating data from animals to humans is either misleading, unnecessary, dangerous, or all three" and the dependence on an animal model is a scientific fallacy supported by mass deception and confusion.

Isaacs, Ronald H. Animals in Jewish Thought and Tradition. Northvale, NJ: Jason Aronson, 2000. 250 p.

Rabbi Isaacs draws on biblical, Talmudic, and midrashic writing for information about the role and relationship of Jews to animals in thought, ritual, liturgy, law, and tradition. The ancient text "Perek Shira," containing songs of praise ascribed to animals, is reprinted.

Kalechofsky, Roberta, ed. Judaism and Animal Rights: Classical and Contemporary Responses. Marblehead, MA: Micah Publications, 1992. $356 \mathrm{p}$.

Classical and contemporary authors address animal research and experimentation from the Jewish perspective; other sections examine vegetarianism and ritual slaughter.

Leahy, Michael P. T. Against Liberation: Putting Animals in Perspective. Revised edition. New York: Routledge, 1994. 286 p.

Leahy draws on Wittgenstein's theories of philosophy of language to argue that animals lack linguistic ability and, therefore, selfconsciousness. He characterizes them as "primitive beings."

Linzey, Andrew. Animal Theology. Urbana: University of Illinois Press, 1995. 214 p.

Linzey holds "that human dominion over animals needs to take as its model the Christgiven paradigm of lordship manifested in service." He extends theological arguments to animals (including constructing a liberation theology), and then addresses specific areas of animal abuse: experimentation, killing for food, genetic engineering, patenting, and sport hunting.

Linzey, Andrew, and Regan, Tom, eds. Animals and Christianity: A Book of Readings. New York: Crossroads, 1988. $210 \mathrm{p}$.

Drawn from classical and contemporary writing, this anthology explores both the compassion and indifference toward animals found within Christianity, as well as the meaning of human dominion over animals, the purpose for which animals were created, and any moral obligations that might arise from the unity of creation.

Mack, Arien, ed. Humans and Other Animals. Columbus: Ohio State University Press, 1999. $439 \mathrm{p}$.

Appearing first as a special issue of the journal Social Research entitled "In the Company of Animals," these conference papers were presented at the New School for Social Research in 1995.

Masson, Jeffrey Moussaieff, and McCarthy, Susan. When Elephants Weep: The Emotional Lives of Animals. New York: Dell Publishing, 1995. $291 \mathrm{p}$.

This best-selling book written for popular audiences uses scientific research and anecdotes to argue that animals possess consciousness and a capacity to feel.

Midgley, Mary. Animals and Why They Matter. Athens: University of Georgia Press, 1984. 158 p. Midgley charges that the rationalist tradition's absolute dismissal of animals as worthy of consideration does not score a clear victory. She argues for an approach that recognizes speciesbased bonds and barriers as important and generally operative, but not exclusive, infallible, or concentric; rather these bonds are overlapping and the boundaries are flexible. Midgley also offers an early examination of the 
relationship between women and animals.

Miller, Harlan B., and Williams, William H., eds. Ethics and Animals. Clifton, NJ: Humana Press, 1983. $400 \mathrm{p}$.

This book contains original papers by seminal thinkers presented at the May 1979 conference "The Moral Foundations of Public Policy: Ethics and Animals" at Virginia Polytechnic Institute and State University. The essays cover the spectrum and diversity of views on humananimal relationships and human uses of animals.

Noske, Barbara. Beyond Boundaries: Humans and Animals. Buffalo, NY: Black Rose Books, 1997. $253 \mathrm{p}$.

Anthropologist and philosopher Noske analyzes the sociohistorical context, cultural notions, and subtle messages of language and their influences on human-animal and animal-human relationships. After exploring continuities and discontinuities between animals and humans, Noske concludes with an anthropology of animals.

On Animal Experimentation: Seeking Common Ground. Cambridge Quarterly of Healthcare Ethics 8 (1): 9-87, Winter 1999. [Special Section]

A series of essays explores the opposing viewpoints in the animal experimentation debate and how the two sides can compromise and reach a "common ground."

Orlans, F. Barbara. In the Name of Science: Issues in Responsible Animal Experimentation. New York: Oxford University Press, 1993. 297 p. Convinced equally of the benefits of research on animal subjects and of the need vigorously to pursue alternatives to harming and killing animals, Orlans provides a comprehensive, balanced, and clear overview of the history, current status, and attitudes toward animal experimentation and alternatives. She also offers the facts about legislation, protocol review, and animal use in education, as well as community participation in animal review committees, international efforts to measure and reduce animal pain and suffering, and the availability of information about animal research.

Orlans, F. Barbara; Beauchamp, Tom L.; Dresser, Rebecca; et al. The Human Use of Animals: Case Studies in Ethical Choice. New York: Oxford University Press, 1998. 330 p.

Sixteen case studies span the broad spectrum of ways humans use animals-e.g., for biomedical, behavioral, and wildlife research; safety testing; education; food and farming; companion animals; and religious rites. The premise that certain characteristics - e.g., self-consciousness, pur-poseful actions, and the ability to reason and communicate - confer on a living creature a certain level of moral standing that then influences ethical choices about animal treatment is asserted in the introduction. Schools of thought, such as utilitarianism, deontological theory, and various animal rights theories, are discussed.

Paul, Ellen Frankel; Miller, Fred D.; and Paul, Jeffrey, eds. Why Animal Experimentation Matters: The Use of Animals in Medical Research. New Brunswick, NJ: Transaction, 2000. 258 p.

Pimple, Kenneth D.; Orlans, F. Barbara; and Gluck, John P., eds. Ethical Issues in the Use of Animals in Research. [Special Issue] Ethics \& Behavior 7 (2): 1997. 192 p.

This is a collection of articles from presentations made at workshops held in 1995 and 1996 entitled "Ethical Issues in Animal Research." The first four essays explore the questions of whether animals have rights, how such rights are derived, and whether animals are members of a moral community. Other essays cover animal experimentation from a religious point of view and look at the role of Institutional Animal Care and Use Committees.

Regan, Tom. The Case for Animal Rights. Berkeley: University of California Press, 1983. $425 \mathrm{p}$. 
In this now classic text, Regan offers a philosophical analysis and argument for animal rights based on a principle of respect and animals' concomitant right not to be harmed.

Regan, Tom, and Singer, Peter. Animal Rights and Human Obligations, 2d ed. Englewood Cliffs, NJ: Prentice Hall, 1989. 280 p.

This rich collection of essays from important historical and contemporary sources presents both sides of the debate about animal rights. Sections on the treatment of farm animals, animals in science, and wildlife are included.

Regan, Tom, ed. Animal Sacrifice: Religious Perspectives on the Use of Animals in Science. Philadelphia: Temple University Press, 1986. $270 \mathrm{p}$.

Scholars draw on scriptural writings, written and oral tradition, law, religious parables, and folklore to explain religious teachings on animals and their use in science. Religions include: Judaism, Christianity, Islam, Hinduism, Jainism, Buddhism, and Confucianism.

Rudacille, Deborah. The Scalpel and the Butterfly: The War Between Animal Research and Animal Protection. New York: Farrar, Strauss and Giroux, 2000. 390 p.

Science writer and former research writer at the Johns Hopkins Center for Alternatives to Animal Testing, Rudacille sets in historical perspective the contributions made to biomedical advances by both scientists and animal protectionists.

Ryder, Richard. Victims of Science. Revised edition. London: National Anti-Vivisection Society, 1983. $180 \mathrm{p}$.

Ryder's comprehensive overview of animal experimentation worldwide provides early statistics on animal use, photographs of animals undergoing experimentation, and a strong argument against continued use of animals in research.

Ryder, Richard D. Animal Revolution:
Changing Attitudes Towards Speciesism. New York: Oxford University Press, 2000. 284 p. Ryder presents an interesting history of humankind's changing attitudes toward and relationships with animals from the ancient world through modern times. Ryder, who coined the term "speciesism," relies chiefly on British history as a framework and emphasizes the influence of the Victorian era on animal welfare in Britain, but does discuss the issue from the broader world perspective.

Scruton, Roger. Animal Rights and Wrongs, 2d ed. London: Demos, 1998. 111 p.

Scruton charges that the arguments of Singer, Regan, and Ryder are philosophically insufficient to support their positions on animal rights and blur the distinction between moral beings and the rest of nature. Scruton argues that animals are not moral beings and do not possess rights, but finds that human beings often have a duty of care toward animals and always must treat them properly as governed by moral considerations stemming from virtue, sympathy, and piety.

Singer, Peter. Animal Liberation, 2d ed. New York: New York Review of Books, 1990. 320 p. The acknowledged inspiration for the modern animal rights movement, Singer argues that the "power of ethical reasoning can prevail over the self-interest of our [human] species" to cause thinking persons to oppose any infliction of suffering on animals. It is, in fact, the capacity to suffer that identifies animals as moral beings. Singer describes the unethical pain and suffering imposed on animals in scientific, military, and commercial animal research and in the food production industry.

Smith, Jane A., and Boyd, Kenneth M., eds. Lives in the Balance: The Ethics of Using Animals in Biomedical Research. New York: Oxford University Press, 1991. 352 p.

This report of a Working Party that the Institute of Medical Ethics in Great Britain established in 1986 to study the ethical issues in the use of 
animals in biomedical research covers philosophical and moral arguments, pain and distress in animals, benefits of research versus harm to animals, and development and use of nonanimal alternatives.

World Congresses on Alternatives and Animal Use in the Life Sciences. Proceedings from . . . Meeting 1, Baltimore, MD, November 1993 [Education, Research, Testing, 1995]; Meeting 2, Utrecht, The Netherlands, October 1996 [Animal Alternatives, Welfare and Ethics, 1997]; Meeting 3, Bologna, Italy, August/September 1999 [Progress in the Reduction, Refinement and Replacement of Animal Experimentation, 2000] Begun in 1993 by Alan Goldberg of the Johns Hopkins Center for Alternatives to Animal Testing, the aims of the Congresses are "to review progress made toward refining, reducing, and replacing (the 3R's) the use of animals in education, research, and testing; to develop a realistic understanding of the status of alternatives; to create an understanding that in research, animal studies, together with clinical studies and in vitro methods, advance science and contribute to our basic understanding of biology and disease; and to promote dialogue between animal protection and scientific communities."

Zurlo, Joanne; Rudacille, Deborah; and Goldberg, Alan M. Animals and Alternatives in Testing: History, Science, and Ethics. New York: Mary Ann Liebert, 1994. 86 p.

The use of animals in toxicity testing, the scientific status of alternatives, and the legal regulations governing animal experimentation are discussed.

\section{Regulating Animal Experimentation}

American Association for Laboratory Animal Science (AALAS). Institutional Animal Care and Use Committees: A Comprehensive Online Resource. [Online at http://www.iacuc.org.]

This site provides an organized resource for institutional animal care and use committees to find information on the Internet. The listserv IACUC-Forum supports the discussion of topics of interest.

American Psychological Association. Committee on Animal Research and Ethics. Guidelines for Ethical Conduct in the Care and Use of Animals. Washington, DC: The Association, 1993. $11 \mathrm{p}$. [Online at http://www.apa.org/science/ anguide.html.]

Canadian Council on Animal Care. Guide to the Care and Use of Experimental Animals. Ottawa, Ontario, Canada: The Council, Vol. 1, 2d ed., 1993, Vol. 2, 1984. [Online at http://www.ccac.ca.]

National Research Council. Commission on Life Sciences. Institute for Animal Laboratory Resources. Guide for the Care and Use of Laboratory Animals. Washington, DC: National Academy Press, 1996. 125 p.

Smith, Adrian. The Regulation of Animal Experimentation in Norway: An Introduction. Oslo: Laboratory Animal Unit, Norwegian School of Veterinary Science, 1998; 22 p. [Online at http://oslovet.veths.no/booklet/Booklet.pdf.]

United Kingdom. Home Office. Draft Guidance on the Operation of the Animals (Scientific Procedures) Act 1986: Consultation [Online at http://www.homeoffice.gov.uk/ccpd/cons.htm.]

\section{Special Topics}

\section{A. Genetic Manipulation of Animals}

Bruce, Donald, and Bruce, Ann, eds. Engineering Genesis: The Ethics of Genetic Engineering in Non-Human Species. London: Earthscan, 1998. $337 \mathrm{p}$.

The Working Group on Genetic Engineering in Non-Human Life Forms of the Society, Religion and Technology Project of the Church of Scotland discusses ethical and theological issues 
associated with genetic engineering and considers the broad social context and implications of this technology. The Group does not find genetic engineering wrong in itself but objects to the rapid pace of developments and the lack of accountability to the public. An appendix contains models to guide decision making about biotechnology.

Canadian Council on Animal Care (CCAC). CCAC Guidelines: On Transgenic Animals, 1997, [Online at http://www.ccac.ca/english/ gdlines/ transgen/transge1.htm] and Transgenic Animals, Animal Welfare and Ethics. Resource (Supplement) 21 (1, Spring/Summer), 1997. 7 p. [Online at http://www.ccac.ca/english/transsup. htm.]

In conjunction with other CCAC statements, these guidelines pertain to the review of transgenic protocols and the production, use, and management of transgenic animals. Ethical standards require that the creation and use of transgenic animals be justified.

Donnelley, Strachan; McCarthy, Charles R.; and Singleton, Rivers, eds. The Brave New World of Animal Biotechnology. Hastings Center Report 24 (1) [Special Supplement], January/February 1994. $32 \mathrm{p}$.

The first major report under the Center's Ethics and Environment Program, these essays address the ethical, legal, scientific, and public policy regulations surrounding the creation and protection of transgenic animals and the environment.

European Commission. Group of Advisers on the Ethical Implications of Biotechnology. Opinion of the Group of Advisers on the Ethical Implication of Biotechnology to the European Commission. Ethical Aspects of Genetic Modification of Animals. No. 7. 21 May 1996. 5 p. [Online at http://europa.eu.int/comm/secretariat_general/sg c/ethics/oldversion/en/biotec10.htm] and Ethical Aspects of Cloning Techniques. No. 9. 28 May 1997. 7 p. [Online at http://europa.eu.int/comm/ secretariat_general/sgc/ethics/oldversion/en/ biotec12.htm.]

These Opinions accept the genetic modification of animals only when the aims of such technology are ethically justified and the conditions for the making, use, care, release, and marketing of genetically modified animals and their products are ethical as assessed on specific points by Member States' licensing bodies.

Fox, Michael W. Beyond Evolution: The Genetically Altered Future of Plants, Animals, the Earth . . . and Humans. New York: Lyons Press, 1999. $256 \mathrm{p}$.

Against a historical overview of developments in the area of genetic engineering of plants and animals, veterinarian/bioethicist Fox focuses on the ethical, social, and environmental consequences he believes will follow from "the development of a new industry and world order based on genetic manipulation, control, and monopoly." He urges an approach that treats animal, plant, and human life with more compassion.

Maclean, Norman, ed. Animals with Novel Genes. Cambridge: Cambridge University Press, 1994. $266 \mathrm{p}$.

Individual chapters examine the actual and potential future contributions of and ethical concerns related to transgenic animals, insects, fish, birds, rodents, large mammals, and minor animal systems in medicine, science, and agriculture.

Mepham, T. Ben; Combes, Robert D.; Balls, Michael; et al. The Use of Transgenic Animals in the European Union: The Report and Recommendations of ECVAM Workshop 28. [Online at http://altweb.jhsph.edu/ science/ pubs/ ECVAM/ecvam28.htm.]

Summarizing the current status of transgenic animal research in the EU, the ECVAM Workshop draws conclusions about this technology, develops a monitoring scheme, and proposes recommendations to aid EU regulatory authorities in formulating regulations governing the appropriate production and use of transgenic 
animals.

\section{Rollin, Bernard E. The Frankenstein} Syndrome- Ethical and Social Issues in the Genetic Engineering of Animals. Cambridge: Cambridge University Press, 1995. 241 p.

Rollin argues that public ability to understand and think about the scientific and ethical concerns truly raised by genetic engineering has been stymied because these technologies are too literally equated with the "Frankenstein myth" of monstrous life. He unpacks these concerns and explains the reasons behind the radical change in the dominant social ethic for the treatment of animals - from a focus simply on anti-cruelty and kindness to an ethic of rights concerned about abuse, suffering, justice, and fairness.

Tudge, Colin. Engineer in the Garden: Genes and Genetics from the Idea of Heredity to the Creation of Life. New York: Hill and Wang, $1995.388 \mathrm{p}$.

Science journalist Trudge offers a history of genetic theory from its classical Darwinian roots in the mid-1800s to its modern day expression in scientific techniques that "engineer" genetics. $\mathrm{He}$ argues that scientific literacy is a requirement for citizenship in the global community because it has become fundamental to our ability to discuss deep philosophical questions about the meaning and manner of life.

U.S. Food and Drug Administration. Center for Biologics Evaluation and Research. Points to Consider in the Manufacture and Testing of Therapeutic Products for Human Use Derived from Transgenic Animals. 1995. [Online at http://www.fda.gov/cber/ptc/ptc_tga.txt.]

This and many other documents regulating transgenic animals and xenotransplantation are available online at http://www.fda.gov/cber/.

Wheale, Peter, and McNally, Ruth, eds. Animal Genetic Engineering: Of Pigs, Oncomice and Men. London: Pluto Press, 1995. 293 p.

Conference papers by scientists, civil servants, biotech entrepreneurs, animal welfare advocates, and philosophers of science ethics address the welfare of transgenic farm and laboratory animals; patenting; production of transgenic animals for disease models, organ sources, or therapeutic products; and the use of embryo transfer and reproductive techniques in animals. A glossary is included.

\section{B. Great Apes}

Blum, Deborah. The Monkey Wars. New York: Oxford University Press, 1994. 306 p.

Science writer Blum's wide-ranging and balanced exploration of the controversial use of primates in research is based on her Pulitzer Prize winning (1992) newspaper articles. She provides a detailed history of primate research and the efforts to regulate and/or end it from her interviews with scientists and researchers on both sides of the issue, as well as with moderate animal advocates and radical activists, and her observations in research laboratories.

Cavalieri, Paola, ed. The Great Ape Project. Etica \& Animali 8: 1-178, 1996.

This international, refereed, research journal devotes the first issue in its English incarnation to discussing and developing the view that nonhuman great apes are the moral equals of human great apes. Contributing authors address the topic from a variety of cultural backgrounds and position it within contemporary debates in evolutionary biology, philosophy of mind, anthropology, and applied ethics. They address how dominant world views must change to support a theory of universal anthropoid rights.

Cavalieri, Paola, and Singer, Peter, eds. The Great Ape Project: Equality Beyond Humanity. New York: St. Martin's Press, 1994. 312 p.

This book launched the Great Ape Project (GAP) as an international movement and its a s s o c i a t e d W e b s i t e (http://www.greatapeproject.org), journal, and newsletter; inspired animal studies courses at 
universities and law schools; and inaugurated a new chapter in the relationship between ethics and ethology. It is edited and written by wellrespected scholars from the sciences and the humanities who are all "committed to the single goal of including nonhuman great apes within the moral community" and extending to them the moral equality and basic rights enjoyed by human great apes. These 34 persons were the authors and first signatories of the "Declaration on Great Apes," which was published here for the first time (see also online at http://www.greatapeproject.org or http://www.planet.it/freewww/gap_etica/ape. $\mathrm{html})$. The declaration contains three principles that must govern relations between human and nonhuman great apes: (1) the right to life; (2) the protection of individual liberty; and (3) the prohibition of torture. GAP is undertaking a census of all great apes during 2001, and the organization's long-term goal is a United Nations Declaration of the Rights of Great Apes.

Coetzee, J. M. The Lives of Animals. Princeton: Princeton University Press, 1999. 127 p.

Awarded the Booker Prize for this book, Coetzee argues for according basic legal rights to animals, especially to the great apes.

Fouts, Roger, with Mills, Stephen Tukel. Next of Kin: What Chimpanzees Have Taught Me about Who We Are. New York: William Morrow, 1997. $420 \mathrm{p}$.

Roger Fouts taught American Sign Language to Washoe, who became the first chimpanzee to communicate with humans by this means. Fouts has enjoyed a 30-year relationship with Washoe, campaigned to improve living conditions for captive research chimps, and founded the Chimpanzee and Human Communications Institute at Central Washington University to train researchers in animal psychology in humane research methods.

National Research Council [NRC] (United States). Commission on Life Sciences. Institute for
Laboratory Animal Research. Committee on Long-Term Care of Chimpanzees. Chimpanzees in Research: Strategies for their Ethical Care, Management, and Use. Washington, DC: National Academy Press, 1997. 92 p.

The Committee studied the dilemma of an overpopulation of U.S. federal research chimpanzees who were bred and born for research, but never were, or no longer are, needed for biomedical research. Recommendations include imposing a five-year breeding moratorium, not endorsing euthanasia for population control, and assuring lifetime support for the core population of chimpanzees.

New Zealand. Animal Welfare Act 1999 (passed into law on 1 October 1999 and operational beginning 1 January 2000). [Online at http://rangi.knowledge-basket.co.nz/gpacts/public/ text/1999/an/142.html.]

This act is the first to grant specific legal protection for nonhuman hominids, Great Apes. It prohibits the use of all great apes in research, testing, or teaching "unless such use is in the best interests of the non-human hominid" or its species and "the benefits to be derived from the use of the non-human hominid in the research, testing, or teaching are not outweighed by the likely harm to the non-human hominid."

Wise, Steven M. Rattling the Cage: Toward Legal Rights for Animals. Cambridge, MA: Perseus Books, 2000. 362 p.

A 20-year practitioner of animal protection law, Wise argues that we must expand fundamental legal and moral rights to encompass great apes because their intelligence and emotional sensitivity demand it, and because failure to do so is unjust and undermines the foundation of human rights. The law must cease its treatment of animals as "things," "objects," or "property."

United Kingdom. Home Secretary's Supplementary Note to the Home Secretary's Response to the Animal Procedures Committee. 6 November 1997.

In response to the Animal Procedures 
Committee 1997 Annual Report (http://www. homeoffice. gov.uk/animact/aspaf.htm), the British Home Office issued a formal government ban on the use of great apes as laboratory animals. Even though the great apes (chimpanzees, gorillas, pygmy gorillas, bonobos, and orangutans) have not been used as laboratory animals even under the Animals (Scientific Procedures) Act 1986, this ban, although not a legislative statute, virtually ensures that great apes will not be used for research in the future.

United States. Congress. House. Committee on Commerce. Subcommittee on Health and Environment. Biomedical Research: Protecting Surplus Chimpanzees: Hearing on H.R. 3514. Serial No. 106-109. 18 May 2000. [Online at http://com-notes.house.gov/cchear/hearings 106. nsf/hemain/.]

"The Chimpanzee Health Improvement, Maintenance and Protection Act" or CHIMP Act would establish a system of sanctuaries for chimpanzees who were bred and used for research by U.S. federal agencies, but are now surplus to the needs of biomedical researchers or are retired from participation in active research. Senate Bill, S. 2725 is the companion bill.

\section{Rats, Mice, and Birds}

Plous, Scott, and Herzog, Harold. Should the AWA Cover Rats, Mice, and Birds? The Results of an IACUC Survey. Lab Animal 28 (6): 38-40, June 1999.

As part of a recent survey of IACUC members, the authors questioned respondents about their attitudes concerning including rats, mice, and birds under the AWA definition of warm blooded animals.

Orlans, F. Barbara. The Injustice of Excluding Laboratory Rats, Mice, and Birds from the Animal Welfare Act. Kennedy Institute of Ethics Journal 10 (3): 229-38, September 2000.

Trull, Frankie L., and Rich, Barbara A. More
Regulation of Rodents [editorial]. Science 284 (5419): 1463, 28 May 1999.

Vergano, Dan. Law Injected into Animal Testing: Researchers Cite Obstacles If More Animals Are Protected. USA Today (31 October 2000). [Online at http://www.usatoday.com/ life/health/general/lhgen108.htm.]

Shalev, Moshe. USDA Agrees to Regulate Rats, Mice, and Birds. Lab Animal 29 (10), November 2000. [Online at http://www.labanimal.com/col/ reg1100.htm.]

United States. District Court. District of Columbia. Animal Legal Defense Fund v. Madigan [Date of Decision: 8 January 1992]. Federal Supplement 781: 797-806, 1992.

The court found that the exclusion of rats, mice, and birds from the definition of "animal" under the Animal Welfare Act was arbitrary and capricious and a violation of the act. The court ordered the USDA to reconsider the plaintiff's rule-making petition. This decision was overturned on appeal to the United States Court of Appeals, District of Columbia Circuit (Animal Legal Defense Fund v. Secretary of Agriculture (Mike Espy). [Date of Decision: 20 May 1994]), which held that the plaintiffs did not demonstrate constitutional standing to sue and/or a statutory right to judicial review under the APA [Administrative Procedure Act].

\section{Science Education and The Use of Animals}

Balcombe, Jonathan. The Use of Animals in Higher Education: Problems, Alternatives and Recommendations. Washington, DC: Humane Society Press, 2000. 104 p. [Online at http://www. hsus.org/programs/research/monograph.html.]

Balcombe, then associate director for education in the animal research issues section of the Humane Society of the United States, focuses on the educational use of animals at the secondary school and college level, especially when there is significant harm or "cost" to the animal, but includes middle school through advanced study 
in graduate, medical, or veterinary schools. He makes 28 recommendations for change.

Drone, Jennifer. PCRM Steps Up Campaign to End Live Animal Laboratories in Medical Education. Good Medicine 8 (1, Winter 1999). [Online at http://www.pcrm.org/magazine/ GM99Winter/GM99Winter5.html.]

Since its creation in 1985, the nonprofit Physicians Committee for Responsible Medicine (PCRM) has worked to promote alternatives to the use of animals in medical schools and medical research. PCRM's education and advocacy campaign has been instrumental in the decisions of 72 of the 127 U.S. medical schools to use "more clinically relevant, humane, and cost-effective alternatives [to live animal research labs]."

Ethical Science and Education Coalition (ESEC) and the New England Anti-Vivisection Society (NEAVS); http://www.neavs.org/esec.html and http://www.neavs.org, respectively.

The educational affiliate of NEAVS, ESEC focuses on dissection and education and advocates for dissection "choice" legislation, offers a guide on "how to pass a student "choice" dissection policy in your school district," and prepares a catalogue of dissection alternatives. Founded in 1895, NEAVS protects and advocates for animals used in education through education, legislation, litigation, and direct action campaigns.

Humane Society of the United States (HSUS). Animals \& Society: A List of Courses (animal ethics, animal rights, animal welfare) [Online at http://www.hsus.org/programs/research/courses. $\mathrm{html}$ ] and Dissection and Related Issues [Online at http://www.hsus.org/programs/research/ animals_education.html].

HSUS provides summaries and contact information about college (and a few veterinary school) courses concerned with animal ethics, animal rights, and/or animal welfare. Listings can be reviewed by discipline or by state. HSUS links to state dissection choice laws, an annotated list of studies on attitudes toward dissection, and other education links to virtual dissections and alternatives databases.

Institute for Laboratory Animal Resources. Commission on Life Sciences. National Research Council. Principles and Guidelines for the Use of Animals in Precollege Education. April 1989. In Fulfilling the Promise: Biology Education in the Nation's Schools, pp. 125-26. Washington, DC: National Research Council, 1990. [Online at http://www4.nas.edu/cls/ilarhome.nsf/web/ Principles/.]

The National Research Council recommends compliance with 10 principles whenever animals are used in precollege education or in science fair projects.

Mukerjee, Madhusree. Trends in Animal Research. Scientific American. [Online at http://www.sciam.com/0297issue/0297trends. html.]

The text of this overview article has been embellished with links to other Web resources.

National Association of Biology Teachers (NABT). The Use of Animals in Biology Education. October 1995. 2 p. [Online at http://www.nabt.org/animals.html.]

A membership association whose mission is to empower "educators to provide the best possible biology and life science education for all students," NABT's policy statement "recommends the prudent and responsible use of animals in the life science classroom." Teachers also "should foster a respect for life" and "teach about the interrelationship and interdependency of all things." NABT endorses and adopts the 10 principles developed by the Institute of Laboratory Animals Resources (ILAR) for the use of animals in precollege education.

Shapiro, Kenneth, and Church, Jill Howard. It's Academic: The Growing Field of Animal Studies. The Animals' Agenda (15 April 2000). [Online at http://www.animalsagenda.org/articledetail.asp? menu $=$ News\&NewsID $=316$.]

Increasing numbers of animal studies courses are being taught at academic institutions. This article provides an overview of these developments; the philosophy behind formalized 
education about animal issues; a comparison of British and American approaches to ethics education by Richard Ryder; and concludes with a sampling of animal-related educational programs, courses, journals, books, conference series, and university appointments.

\section{E. Xenotransplantation: Transplanting Animal Organs into Humans}

Cooper, David K.C., and Lanza, Robert P. Xeno: The Promise of Transplanting Animal Organs into Humans. New York: Oxford University Press, 2000. 274 p.

Fox, Marie, and McHale, Jean. Xenotransplantation: The Ethical and Legal Ramifications. Medical Law Review 6 (1): 42-61, Spring 1998.

France. National Consultative Bioethics Committee for Health and Life Sciences. Opinion on Ethics and Xenotransplantation: Opinion No. 61. Paris: The Committee, 11 June 1999. 16 p. [Online at http://www.ccneethique.org/english/avis/ a_061.htm\#deb.]

Great Britain. Department of Health. Advisory Group on the Ethics of Xenotransplantation. Animal Tissue into Humans: A Report by The Advisory Group on the Ethics of Xenotransplantation. London: Stationery Office, 1996. 258 p.

Institute of Medicine [IOM] (United States). Division of Health Sciences Policy. Committee on Xenograft Transplantation: Ethical Issues and Public Policy. Xenotransplantation: Science, Ethics and Public Policy. Washington, DC: National Academy Press, 1996. 126 p.

Nuffield Council on Bioethics Animal-to-Human Transplants: The Ethics of Xenotransplantation. London, England: The Council, 1996. 147 p. [Partially online at http://www.nuffield.org/ bioethics/publication.]
This report addresses alternatives to xenotransplants, the likely success of xenotransplants, concerns regarding the rights and welfare of the animals used, the potential for transmitting infections, and other ethical and social implications.

United States. Department of Health and Human Services. PHS Guideline on Infectious Disease Issues in Xenotransplantation: Draft-Not for Implementation. Washington, DC: The Department, October 2000. 58 p. [Online at http: //www.fda.gov/cber/gdlns/xenophs1000.pdf.]

Veatch, Robert M. The Ethics of Xenografts. In his Transplantation Ethics, pp. 259-73. Washington, DC: Georgetown University Press, 2000.

This chapter includes an overview of the issues raised in xenotransplantation since Baby Fae was given a chimpanzee heart in 1984 .

The authors acknowledge the advice and contributions of F. Barbara Orlans, Ph.D., Senior Research Fellow; Harriet Hutson Gray, M.T.S., M.S.L.S., Reference and Digital Librarian; and Doris M. Goldstein, M.L.S., M.A., Director of Library and Information Services, all at the Kennedy Institute of Ethics; and John P. Gluck, Ph.D., Professor, Department of Psychology, University of New Mexico, in the preparation of this Scope Note.

Produced at the National Reference Center for Bioethics Literature, Kennedy Institute of Ethics, Georgetown University, Box 571212, Washington, DC 20057-1212. The Center operates on Contract N01 LM73529 from the National Library of Medicine, National Institutes of Health. Additional support is provided by Grant P4 1 HG01115 from the ELSI Program, National Human Genome Research Institute, National Institutes of Health, and by other public and private sources.

Reprint issued March 2001. 